National Marine

Fisheries Service

NOAA
Fishery Bulletin

a established in 1881 a
Spencer F. Baird

First U.S. Commissione of Fisheries and founder of Fishery Bulletin

\begin{abstract}
The narrownose smoothhound (Mustelus schmitti) is the most exploited elasmobranch of Argentina, Brazil, and Uruguay and is considered endangered (IUCN Red List of Threatened Species). Providing information on age and growth can improve efforts for conservation of this species. Therefore, our objective was to provide accurate estimates of the age structure and growth parameters for narrownose smooth-hound from Anegada Bay, an important shark nursery area in Argentina. In vertebrae of narrownose smooth-hound, we observed a pattern of alternating opaque and translucent bands and a yearly periodicity in the deposition of this pattern. Ages determined from vertebral band counts ranged from 0 to 11 years. Calculated longevity and total natural mortality rates were 20.87 years and 0.19 /year for females and 12.24 years and $0.26 /$ year for males, respectively. This species reached a size of approximately 400 $\mathrm{mm}$ in total length in the initial year of growth, and the age at first maturity was 7.61 years for females and 6.79 years for males. The slow growth and late age at maturity of the narrownose smoothhound indicate a need for additional conservation measures to rebuild the population and achieve a sustainable fishery in the 3 countries in which it is distributed.
\end{abstract}

Manuscript submitted 19 June 2016. Manuscript accepted 9 May 2017. Fish. Bull. 115:365-379 (2017). Online publication date: 8 June 2017. doi: 10.7755/FB.115.3.7

The views and opinions expressed or implied in this article are those of the author (or authors) and do not necessarily reflect the position of the National Marine Fisheries Service, NOAA.

\title{
Age and growth of the highly exploited narrownose smooth-hound (Mustelus schmitti) (Pisces: Elasmobranchii)
}

\author{
Juan M. Molina (contact author) ${ }^{1}$ \\ Gabriela E. Blasina ${ }^{2}$ \\ Andrea C. Lopez Cazorla ${ }^{1,2}$ \\ Email address for contact author: jmmolina@criba.edu.ar \\ 1 Departamento de Biología, Bioquímica y Farmacia \\ Universidad Nacional del Sur \\ San Juan 670, Primer Piso \\ 8000 Bahía Blanca, Buenos Aires, Argentina \\ 2 Instituto Argentino de Oceanografía \\ Consejo Nacional de Investigaciones Científicas y Técnicas \\ Florida 8000 (Camino La Carrindanga km 7,5) \\ 8000 Bahía Blanca, Buenos Aires, Argentina
}

The Chondrichthyes make up a class of vertebrates that are usually described as late-maturing fish with a moderate-to-long life span and an extended gestation period that produces a low number of developed offspring (Dulvy et al., 2008). Most chondrichthyans have limited geographic distributions and gather in schools by age, sex, and reproductive states (Barker and Schluessel, 2005). The characteristic slow population growth of these elsasmobranchs renders them highly vulnerable to fishing pressure (Dulvy et al., 2008; Cortés et al., 2010). Globally, chondrichthyan fish populations are declining (Camhi et al. ${ }^{1}$ - a fact aggravated by a lack of knowledge of the biology for many species. This lack of information makes identifying threats to

\footnotetext{
${ }^{1}$ Camhi, M. D., S. V. Valenti, S. V. Fordham, S. L. Fowler, and C. Gibson (eds.). 2007. The conservation status of pelagic sharks and rays. Report of the IUCN Shark Specialist Group Pelagic Shark Red List Workshop, 78 p. IUCN Species Survival Commission Shark Specialist Group, Newbury, UK.
}

conservation challenging, and designing appropriate management measures almost impossible (Molina and Cooke, 2012).

The narrownose smooth-hound (Mustelus schmitti) is a small shark in the family Triakidae that attains a maximum total length (TL) of 110 $\mathrm{cm}$ (Menni, 1985). Endemic to the southwest Atlantic Ocean, this shark occurs in waters over the continental shelf, from coastal waters of less than $50 \mathrm{~m}$ to depths up to $120 \mathrm{~m}$, throughout its range from southeastern Brazil to the Argentinean Patagonia (from $22^{\circ} \mathrm{S}$ to $47^{\circ} \mathrm{S}$ ) (Menni, 1985). This shark is known to migrate seasonally, in large numbers, between wintering grounds in southern Brazil and summering grounds in Argentina (Figueiredo, 1977; Vooren, 1997). Seasonally, it also frequents estuaries, protected bays, and gulfs (Lopez Cazorla, 1987; Chiaramonte and Pettovello, 2000; Colautti et al., 2010; Molina, 2013).

The narrownose smooth-hound is the most exploited elasmobranch species (by both industrial and artisanal 
fishing fleets) found on the continental shelf in Argentina, Brazil, and Uruguay (Massa and Lasta ${ }^{2}$ ). The exploitation of this species throughout its range has led to declines in its population (Massa et al. ${ }^{3}$ ), and it has a global classification of endangered (IUCN Red List of Threatened Species), with a designation of vulnerable in Argentina and Uruguay (Massa et al., 2006). Narrownose smooth-hound caught off the coast of Brazil are part of the southern stock that migrates north every year. Therefore, the exploitation in nursery areas, in particular, has led to recruitment overfishing and a decline of $~ 85 \%$ in the total biomass from 1975 to 1995 (Haimovici, 1997). In Brazil, this species is categorized as critically endangered in the IUCN Red List of Threatened Species (Massa et al., 2006). Given its migratory behavior, there is great concern for the conservation of this shark over its entire range of distribution (Massa et al., 2006; Molina and Lopez Cazorla, 2011).

Sustainable fishing of small coastal sharks, which have a greater recovery potential (Stevens et al., 2000) than their larger counterparts, is theoretically possible to achieve if the key biological aspects are taken into consideration when designing management policy. The narrownose smooth-hound is one of the most studied sharks of Argentina: several scientific publications describe its reproduction, food habits, and other aspects of its biology (Menni, 1985; Menni et al., 1986; Cousseau et al. ${ }^{4}$; Chiaramonte and Pettovello, 2000; Sidders et al., 2005; Cortés and Massa ${ }^{5}$; Segura and Milessi, 2009; Colautti et al., 2010; Molina and Lopez Cazorla, 2011). However, little attention has been paid to age and growth of this species. To date, there are 2 documents, a M.S, thesis from Brazil (Batista, 1988) and a technical report from Argentina (Hozbor et al. ${ }^{6}$ )

\footnotetext{
2 Massa, A., and C. A. Lasta. 2000. Recursos a mantener: Gatuzo (Mustelus schmitti). In Síntesis del estado de las pesquerías marítimas argentinas y de la Cuenca del Plata. Años 1997-1998, con una actualizacion de 1999. Publicaciones Especiales INIDEP (S. I. Bezzi, R. Akselman, and E. E. Boschi, eds.), p. 129-137. [Available from Instituto Nacional de Investigación y Desarrollo Pesquero, Paseo Victoria Ocampo $\mathrm{N}^{\circ} 1$, Escollera Norte, B7602HSA Mar del Plata, Provincia de Buenos Aires, Argentina.]

3 Massa, A., C. A. Lasta, and C. R. Carozza. 2004. Estado actual y explotación del gatuzo (Mustelus schmitti). In Los peces marinos de interés pesquero. Caracterización biológica y evaluación del estado de explotación. Publicaciones Especiales INIDEP (R. P. Sánchez and S. I. Bezzi, eds.), p. 67-83. [Available from Instituto Nacional de Investigación y Desarrollo Pesquero, Paseo Victoria Ocampo $\mathrm{N}^{\circ} 1$, Escollera Norte, B7602HSA Mar del Plata, Provincia de Buenos Aires, Argentina.]

${ }^{4}$ Cousseau, M. B., C. R. Carozza, and G. J. Macchi. 1998. Abundancia, reproducción y distribucion de tallas del gatuzo (Mustelus schmitti) en la Zona Común de Pesca ArgentinoUruguaya y en El Rincón. Noviembre, 1994. INIDEP Inf. Tec. 21:103-115. [Available from website.]

${ }^{5}$ Cortés, F., and A. Massa. 2006. Aspectos reproductivos del gatuzo (Mustelus schmitti). Inf. Téc. INIDEP, 10 p. [Available from website.]

${ }^{6}$ Hozbor, N. M., M. Sáez, and A. M. Massa. 2010. Edad y crecimiento de Mustelus schmitti (gatuzo), en la región costera bonaerense y uruguaya. INIDEP Inf. Invest. 49, $15 \mathrm{p}$. [Available from website.]
}

that deal with this aspect. Science-based studies on age and growth are crucially important for research of population dynamics because, without accurate age and growth estimations, it is impossible to perform adequate fisheries stock assessments, make accurate forecasts, and provide effective management (Chugunova, 1963; Reeves, 2003; Methot and Wetzel, 2013). Therefore, the aim of this work was to provide accurate estimates of the age structure and growth parameters for the population of narrownose smooth-hound from Anegada Bay, an important shark breeding area in Argentina.

\section{Materials and methods}

\section{Study area}

Anegada Bay, located in the south of Buenos Aires Province in Argentina, has a wide variety of habitats, including wide, muddy intertidal areas, sandy bottom substrates, and sand and gravel beaches. In Anegada Bay, a multi-use protected area, the Reserva Natural de Uso Múltiple Bahía San Blas, was designated in 2001 (Provincial Law 12788; available from website), as a means of preserving not only fish species but also a wide variety of vertebrate species, such as several migratory birds, sea lions, and terrestrial mammals, that use the bay as nesting and feeding grounds. This bay is also considered a potential nursery area for narrownose smooth-hound (Molina and Lopez Cazorla, 2011). Artisanal and recreational fisheries were the main human activities in Anegada Bay. Whereas the latter still continues, in recent years, artisanal fishing has been prohibited within the boundaries of the reserve.

This study was conducted in the southern part of Anegada Bay, where 3 sampling stations were established: San Blas, Ría, and Los Pocitos (Fig. 1).

\section{Sampling methods and data collection}

Specimens of narrownose smooth-hound were collected seasonally in 2008: in February (summer), May (autumn), August (winter), and November (spring). The fishing gear consisted of 2 batteries of 7 bottom gill nets. Each net was $25 \mathrm{~m}$ long, $2 \mathrm{~m}$ high, and had different mesh sizes $(64,70,80,105,135,150$, and 170 $\mathrm{mm}$ stretched) so that a wide range of fish sizes could be captured. Nets were placed parallel to the coast of the sampling stations at dusk, and collected 12 hours later at dawn.

All fish were first measured in situ to the nearest centimeter in TL and subsequently grouped into $1-\mathrm{cm}$ size classes. A subsample composed of 10 randomly selected specimens of each size class was then used for further analysis. These 10 individuals were measured to the nearest millimeter in TL, their sex was determined, and the portion of vertebral column from below the first dorsal fin was removed. Vertebrae portions were 
stripped of soft tissue with a scalpel and frozen for transportation and storage.

\section{Preparation and sectioning of vertebrae}

Vertebrae were prepared by following the methods described in Cailliet et al. (1990), Moulton et al. (1992), Natanson et al. (1995), Campana (2001), Conrath et al. (2002), and Lessa et al. (2016). Samples were cleaned of excess tissue and separated into individual centra so that they could be submerged in a solution of $2.5 \%$ sodium hypochlorite to remove connective tissue, without compromising the interpretability of growth bands. Bath duration varied between 5 and $30 \mathrm{~min}$, depending on the size of the centra. Afterward, vertebrae were rinsed with tap water, air dried, and mounted on transparent epoxy resin. One section (approximately $0.2 \mathrm{~mm}$ thick) was then cut transversely through the focus with a diamond-bladed IsoMet Low Speed Saw (Bueheler, Lake Bluff, IL).

\section{Age determination}

Vertebral sections were examined under a binocular microscope with transmitted light to identify opaque (hypomineralized, wide) and translucent (hypermineralized, narrow) bands. All counts were made with no knowledge of size, sex, or date of capture of the individual. The birth mark was identified by the angle change in growth bands and by the banding patterns on neonates and embryos. Bands consisting of opaque and translucent areas were identified along the corpus calcareum (Goldman et al., 2012) (Fig. 2) in each vertebra. Variation in the nature of the border of the vertebra was used to verify the temporal periodicity of the formation of each band type (Campana, 2001). The age of each individual fish was determined by the number of translucent bands, the date of capture, and the date of birth, which was assumed to be 1 January. This assumption is supported by the fact that a high proportion of gravid females were captured in a previous sampling campaign in December 2007 and by the high number of young of the year captured in February 2008 (Colautti et al., 2010). For example, a fish that was captured on 12 February 2008 and had 2 bands was calculated to have an age of $408 \mathrm{~d}$ (1.12 years).

Bias and precision of age estimations were assessed according to the methods proposed by Goldman et al. (2012). The thin sections of vertebrae from the same

\footnotetext{
${ }^{7}$ Mention of trade names or commercial companies is for identification purposes only and does not imply endorsement by the National Marine Fisheries Service, NOAA.
}

specimen were read twice by 2 different readers, and the analysis of bias in age determination was carried out with a bias plot (Campana et al., 1995; Officer et al., 1996). The indices of average percent error (Beamish and Fournier, 1981) and the average coefficient of variation (Chang, 1982) were calculated to assess the precision of the age determination between the 2 readers as well as between both readings of each reader (Ogle, 2015). Differences in readings between readers were reconciled by both readers reading a third time the samples for which they had different band counts. If agreement on a band count was not reached with the additional readings, the sample was eliminated from further analysis.

\section{Estimates of somatic growth}

To model growth, we used partial ages because they have been shown to be more accurate than rounded ages (Smart et al., 2013). To calculate the partial ages, we used the fraction of the year that had elapsed from the time of birth to the time each individual was collected. Partial ages were then grouped in 0.5-year bins. 


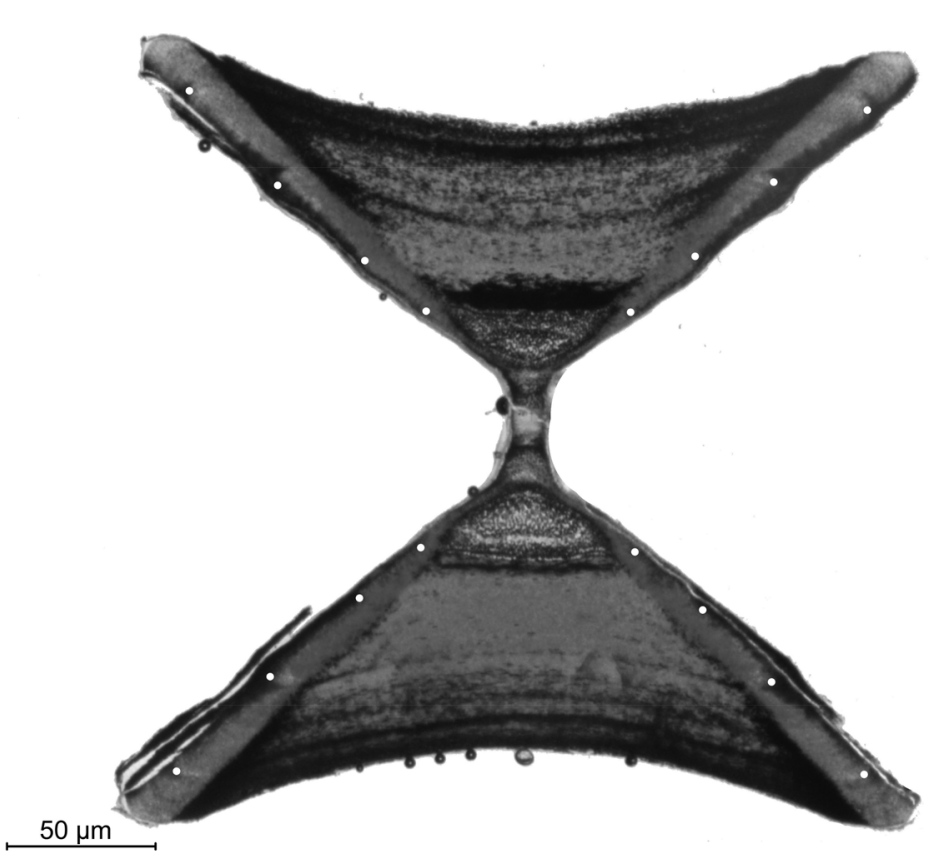

Figure 2

Image of a transverse section of the centrum of a vertebra of a narrownose smooth-hound (Mustelus schmitti) caught in Anegada Bay, Argentina, in 2008. The white dots indicate growth bands (narrow and hypermineralized). The first dot from the centrum is the birth mark.

is biologically meaningful for chondrichtyan fishes (Cailliet et al., 2006). The parameter $L_{\infty}$ can be compared directly between models (the Francis parameterization of the VBGF allows for calculation of $L_{\infty}$ and $K$; Ogle, 2015 ). In contrast, the parameters of growth completion of each model, $K$ (VBGF), $G$ (Gompertz), g (logistic), and $G_{\text {init }}$ (Mooij), cannot be compared because they are measures of different processes.

For each model, the parameter estimates that were best fitted to the data were calculated by using the nls function in the statistical software R, vers. 3.2.4 (R Core Team, 2016) and specific functions from the FSA package, vers. 0.8.1, in R (Ogle, 2015).

Back-calculation methods are used to describe the growth history (lengths at previous ages) of each individual fish, and currently there are many approaches in use: Francis (1988) provides a thorough revision of back-calculation methods, and Goldman et al. (2012) and Cailliet et al. (2006) provide a review of these methods applied to chondrichthyan fishes. We employed a Fraser-Lee approach to back calculate the length-at-age data, with which we fitted our models to estimate the growth parameters, and compared length at ages calculated from our observational data.

To assess the fit of each model, we used a bias-corrected Akaike information criterion

We modeled growth by using a multimodel approach, a method recommended over the use of a single-model approach (Cailliet et al., 2006; Katsanevakis and Maravelias, 2008; Ogle, 2015). To fit the age data, 7 candidate growth models were chosen a priori: 3 variants of the von Bertalanffy growth function (VBGF) (von Bertalanffy, 1938), plus Francis and Mooij parameterizations of the VBGF model (Table 1; Francis, 1988; Mooij et al., 1999); the logistic function (Ricker, 1976); and the Gompertz function (Gompertz, 1825) with the parameterization of Ricker (1976). The 3 variants of the VBGF model used the original, traditional, and fixed lengthat-birth parameter $\left(L_{0}\right)$, respectively. The advantage of the model with the Francis parameterization lies in the noncorrelation between the growth coefficient $(K)$ and the asymptotic length $\left(L_{\infty}\right)$ parameters (Francis, 1988). The model with the Mooij parameterization estimates the $\left(G_{\text {init }}\right)$ parameter, which has a clear biological interpretation as the initial growth rate in length per year; in contrast, the VBGF growth parameter $K$ cannot be interpreted biologically (Mooij et al., 1999).

For the fixed- $L_{0}$ variant model and the model with the Mooij parameterization, $L_{0}$ was calculated by following Conrath (2005) and using a value that represents a compromise between the largest embryo and the smallest free-living individual captured. For the original VBGF and logistic models, $L_{0}$ was estimated by the nonlinear least-squares routine. The use of $L_{0}$
(AICc) and the Bayesian information criterion (BIC) (Burnham and Anderson, 2002; Katsanevakis, 2006; Zhu et al., 2009; Lopez Cazorla et al., 2014). The model with the lowest AICc and BIC values was chosen as the most appropriate to describe the growth of narrownose smooth-hound.

Differences, by sex, in estimates of growth parameters from the selected model were assessed with likelihood ratio tests (Kimura, 1980) and extra sumof-squares tests (Ritz and Streibig, 2008). To identify which growth parameter differ between sexes, we fitted iterative models: the most complex model represents the case where all 3 growth parameters differ among sexes. The simplest model represents the case where none of the parameters differ between females and males. Between these 2 extremes, we built 3 models where 2 parameters differ and 3 models where only 1 parameter differs between sexes (Ogle, 2015). Protocols for selection of AICc and BIC were used to select the most appropriate model, as described previously.

To test the overall growth performance, the growth performance index $(\phi)$ was calculated (Pauly, 1984) by employing the parameters from the selected model:

$$
\phi=\log _{10} K+2 \log _{10} L_{\infty} .
$$

This index is useful because it reduces the correlation between $L_{\infty}$ and $K$, and that reduction is desirable for comparisons of growth among studies of different species. 


\section{Table 1}

Equations of the 7 growth models fitted to the length-at-age data of narrownose smooth-hound (Mustelus schmitti) collected in 2008 in Anegada Bay, Argentina, where VBGF=the von Bertalanffy growth function; $L_{\mathrm{t}}=$ length at age $t ; L_{0}=$ length at age $0 ; L_{0}{ }^{*}=$ the fixed length at age $0 ; t_{1}=$ age $1 ; t_{3}$ the maximum age recorded;, $t_{2=}$ an age between $t_{1}$ and $t_{3} ; L_{1}=$ length at age $t_{1}$; $L_{2}=$ length at age $t_{1} ; L_{3}=$ length at age $t_{3} ; L_{\infty}=$ asymptotic length; and $K, g$, $G$, and $G_{\text {init }}=$ the growth coefficients of the different models. In the Francis model, $r=\left(L_{3}-L_{2}\right) /\left(L_{2}-L_{1}\right)$. In the Gompertz model, $a=$ the instantaneous growth rate at the inflection point of the curve.

\begin{tabular}{cl}
\hline Model & \multicolumn{1}{c}{ Growth function } \\
\hline Original VBGF & $L_{\mathrm{t}}=L_{0}+\left(L_{\infty}-L_{0}\right) \times\left(1-\exp ^{[-\mathrm{K} \times \mathrm{t}]}\right)$ \\
Traditional VBGF & $L_{\mathrm{t}}=L_{\infty} \times\left(1-\exp ^{[-\mathrm{K}(\mathrm{t}-\mathrm{t} 0)]}\right)$ \\
Fixed- $L_{0}$ VBGF & $L_{\mathrm{t}}=L_{0} *\left(L_{\infty}-L_{0} *\right) \times\left(1-\exp ^{(-\mathrm{K} \times \mathrm{t})}\right)$ \\
Francis & $L_{\mathrm{t}}=L_{1}+\left(L_{3}-L_{1}\right) \times\left(\left[1-r^{2([\mathrm{t}-\mathrm{t} 1] /[\mathrm{t} 3-\mathrm{t} 1])]} /\left[1-r^{2}\right]\right)\right.$ \\
Mooij & $L_{\mathrm{t}}=\left(G_{\mathrm{init}} \times\left[L_{\infty}-L_{0} *\right] / L_{\infty}\right) \exp ^{(\mathrm{Ginit} / \mathrm{L} \infty \mathrm{t}}$ \\
Logistic & $L_{\mathrm{t}}=\left(L_{0} \times L_{\infty}\right) /\left(L_{0}+\left[L_{\infty}-L_{0}\right]\right) \exp ^{(-\mathrm{g} \times \mathrm{t})}$ \\
Gompertz & $L_{\mathrm{t}}=L_{0} \times\left(\exp ^{\mathrm{G}[1-\exp (-\mathrm{g} \times \mathrm{t})]}\right)$ \\
&
\end{tabular}

The longevity was assumed to be the age at $95 \%$ of $L_{\infty}$ by using Fabens (1965) equation. Natural mortality $(M)$ was calculated, by following Booth et al. (2011), as the median of the empirical model of Pauly (1980), Hoenig (1983), and Jensen (1996):

$$
\begin{gathered}
M_{(\text {Pauly })}=\exp \left(-0.0152-0.279 \ln L_{\infty}\right. \\
+0.6543 \ln K+0.463 \ln T), \\
\left.M_{(\text {Hoenig })}=\exp \left(1.44-0.982 \ln t_{\max }\right)\right), \text { and } \\
M_{(\text {Jensen })}=1.6 K,
\end{gathered}
$$

where $L_{\infty}$ and $K=$ the VGBF model parameters;

$T=$ the mean water temperature $\left(12.7^{\circ} \mathrm{C}\right)$; and

$t_{\max }=$ the age of the oldest fish sampled (Hoenig, 1983).

\section{Results}

A total of 1577 narrownose smooth-hound, with sizes ranging from 300 to $810 \mathrm{~mm}$ TL (mean: $460 \mathrm{~mm}$ TL [standard error (SE) $90 \mathrm{~mm}$ ]; mode: $390 \mathrm{~mm}$ TL), were collected. Of these sharks, 245 were subsampled. Sizes of subsampled fish ranged from 320 to $810 \mathrm{~mm}$ TL (mean: $490 \mathrm{~mm}$ [SE $90 \mathrm{~mm}$ TL]; mode: $400 \mathrm{~mm}$ TL) (Fig. 3 ). Of the fish examined, $52.46 \%$ were females, ranging in size between 331 and $810 \mathrm{~mm}$ TL, and $47.54 \%$ were males, with a size range of $320-791 \mathrm{~mm}$ TL.

In the vertebrae of narrownose smooth-hound, we observed a pattern of alternating opaque and translucent bands and an annual cycle in the seasonal evolution of the proportion of translucent edges (Fig. 4). Vertebrae with translucent margins increased in February (summer), reached a $76 \%$ peak in May (autumn), and decreased to a value of approximately $11 \%$ from August (winter) to November (spring).These data indicate a yearly periodicity in translucent band formation. The total number of individuals used for this analysis was slightly smaller than the total subsample number because of illegibility of the edge of the vertebra of 23 individuals. This illegibility was the result of an error in the concentration of hypochlorite used for cleaning. The outer layer of these 23 vertebrae was corroded by hypochlorite and, therefore, was illegible.

The ages determined for the total population ranged from 0 to 11 years. A pattern of increase in length with age was observed (Table 2); however, this pattern was not consistent at some ages, particularly at ages of 0-1 years and above 6-7 years, where the number of individuals was proportionally low. Results for backcalculated length at age indicated a more consistent pattern of increase in length with age but also abrupt leaps in length at older ages. The age bias plot shows no systematic bias between the 2 readers (Fig. 5), with a range of error from -2 to 1 band, and a percentage of agreement of $82.45 \%$. Estimation of ages was highly precise, according to the average percent error and average coefficient of variation $(4.54 \%$ and $3.23 \%$, respectively). Band counts by reader 1 had a range of error of -3 to 3 bands and a percentage of agreement of $87.82 \%$. Obtained values of average percent error and average coefficient of variation for reader 1 indicate a precise age estimation ( $3.94 \%$ and $2.79 \%$, respectively). Band counts by reader 2 had a range of error from -4 to 3 bands and a percentage of agreement of $82.88 \%$. Average percent error and average coefficient of variation for reader 2 indicate precise age estimation $(3.05 \%$ and $2.15 \%$, respectively).

Age 1 was the most predominant age for both sexes, representing $19.54 \%$ of all females and $19.64 \%$ of all males, followed by age 2 for females with $18.04 \%$ and age 3 for males with $17.85 \%$ (see Table 2).

Our back calculation of length-at-age data produced 2162 observations. Back-calculated mean and SE values are presented in Table 2. Although within the SE 


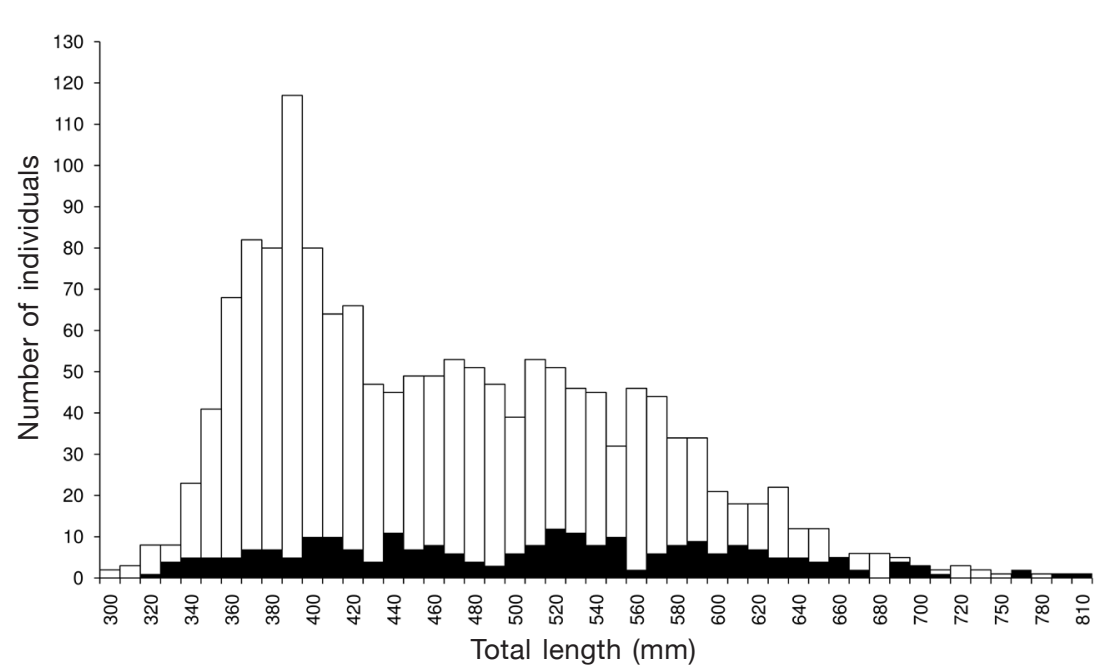

Figure 3

Size distribution of the narrownose smooth-hound (Mustelus schmitti) caught in Anegada Bay, Argentina, in 2008. The white bars represent the total sample $(n=1547)$ at a given total length, and the black bars represent the subsample composed of 10 randomly selected specimens of each size $(n=245)$. Samplings were conducted in February (summer), May (autumn), August (winter) and November (spring).

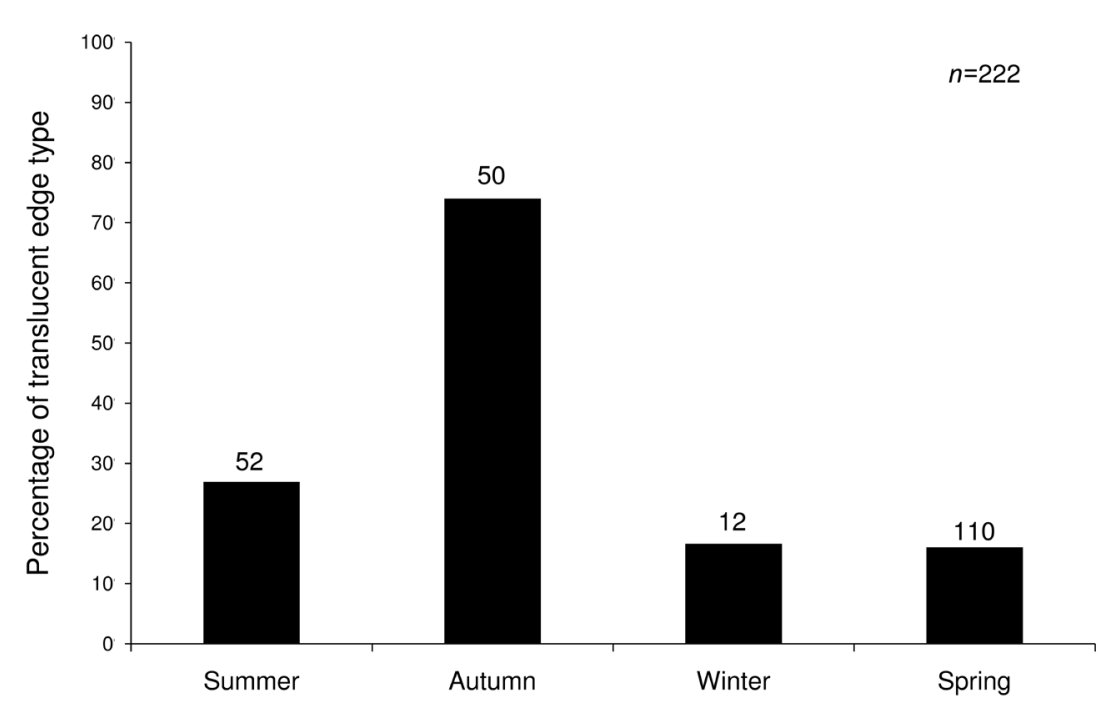

Figure 4

Seasonal change in the percentage of translucent bands at the edge of the vertebrae of narrownose smooth-hound (Mustelus schmitti) caught in Anegada Bay, Argentina, in 2008. The numbers above the bars indicate the number of individuals sampled in each season. Sampling was conducted seasonally in February (summer), May (autumn), August (winter), and November (spring). Note that the vertebrae of 222 individuals were used for age determination-a number slightly smaller than the the size of the subsample $(n=245)$ because 23 individuals were not used as a result of the ilegibility of the edge of their vertebrae. 
Table 2

Mean length at age of male and female narrownose smooth-hound (Mustelus schmitti) collected in 2008 in Anegada Bay, Argentina, according to vertebral readings. Fish lengths are given as total lengths (TLs) in centimeters, with standard errors (SEs). Back-calculation methods are used to describe the growth history (lengths at previous ages) of each individual fish sampled, providing a much larger sample size to perform modeling of growth to compare with growth from the observed data.

\begin{tabular}{|c|c|c|c|c|c|c|c|c|c|c|c|c|}
\hline \multirow[b]{3}{*}{ Age } & \multicolumn{6}{|c|}{ Observed data } & \multicolumn{6}{|c|}{ Back-calculated data } \\
\hline & \multicolumn{3}{|c|}{ Females } & \multicolumn{3}{|c|}{ Males } & \multicolumn{3}{|c|}{ Females } & \multicolumn{3}{|c|}{ Males } \\
\hline & $n$ & Mean TL & $\mathrm{SE}$ & $n$ & Mean TL & $\mathrm{SE}$ & $n$ & Mean TL & $\mathrm{SE}$ & $n$ & Mean TL & $\mathrm{SE}$ \\
\hline 0 & 2 & 364.5 & 44.6 & 7 & 348.3 & 50.2 & 247 & 372.0 & 35.7 & 237 & 369.4 & 37.2 \\
\hline 1 & 26 & 396.7 & 38.4 & 22 & 390.8 & 43.1 & 223 & 437.3 & 48.4 & 187 & 440.2 & 46.5 \\
\hline 2 & 24 & 451.2 & 54.9 & 17 & 451.1 & 39.5 & 175 & 498.1 & 50.9 & 145 & 495.4 & 47.0 \\
\hline 3 & 13 & 489.7 & 63.4 & 20 & 504.5 & 40.3 & 142 & 540.9 & 52.6 & 110 & 530.2 & 46.8 \\
\hline 4 & 10 & 522.4 & 49.0 & 14 & 551.9 & 40.2 & 126 & 572.3 & 48.8 & 75 & 559.1 & 45.3 \\
\hline 5 & 10 & 553.1 & 62.6 & 9 & 570.3 & 39.3 & 100 & 591.9 & 49.6 & 66 & 582.1 & 46.3 \\
\hline 6 & 11 & 584.0 & 43.4 & 8 & 576.1 & 51.5 & 87 & 616.6 & 55.1 & 39 & 596.9 & 45.9 \\
\hline 7 & 10 & 587.3 & 50.2 & 5 & 601.6 & 47.2 & 63 & 639.5 & 51.4 & 24 & 625.2 & 43.7 \\
\hline 8 & 6 & 618.3 & 45.0 & 5 & 615.8 & 27.2 & 41 & 654.6 & 46.2 & 19 & 658.9 & 64.0 \\
\hline 9 & 9 & 634.7 & 38.9 & 3 & 661.0 & 48.5 & 24 & 692.4 & 51.5 & 12 & 681.6 & 50.9 \\
\hline 10 & 9 & 687.8 & 35.0 & 1 & 669.0 & & 14 & 733.7 & 45.8 & 2 & 718.7 & 86.9 \\
\hline 11 & 3 & 755.7 & 61.2 & 1 & 791.0 & & 2 & 761.0 & 0.0 & 2 & 791.0 & 0.0 \\
\hline
\end{tabular}

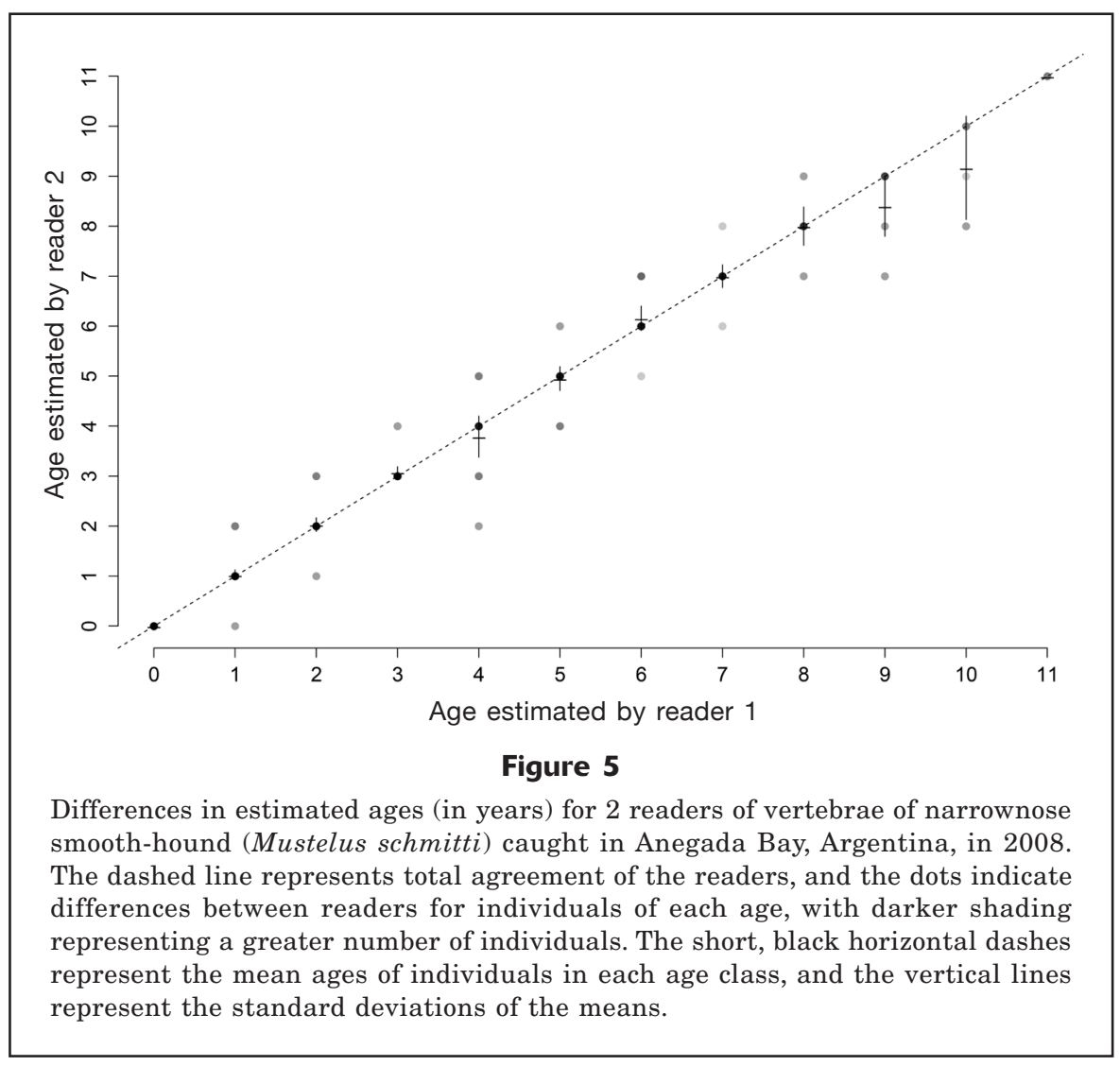



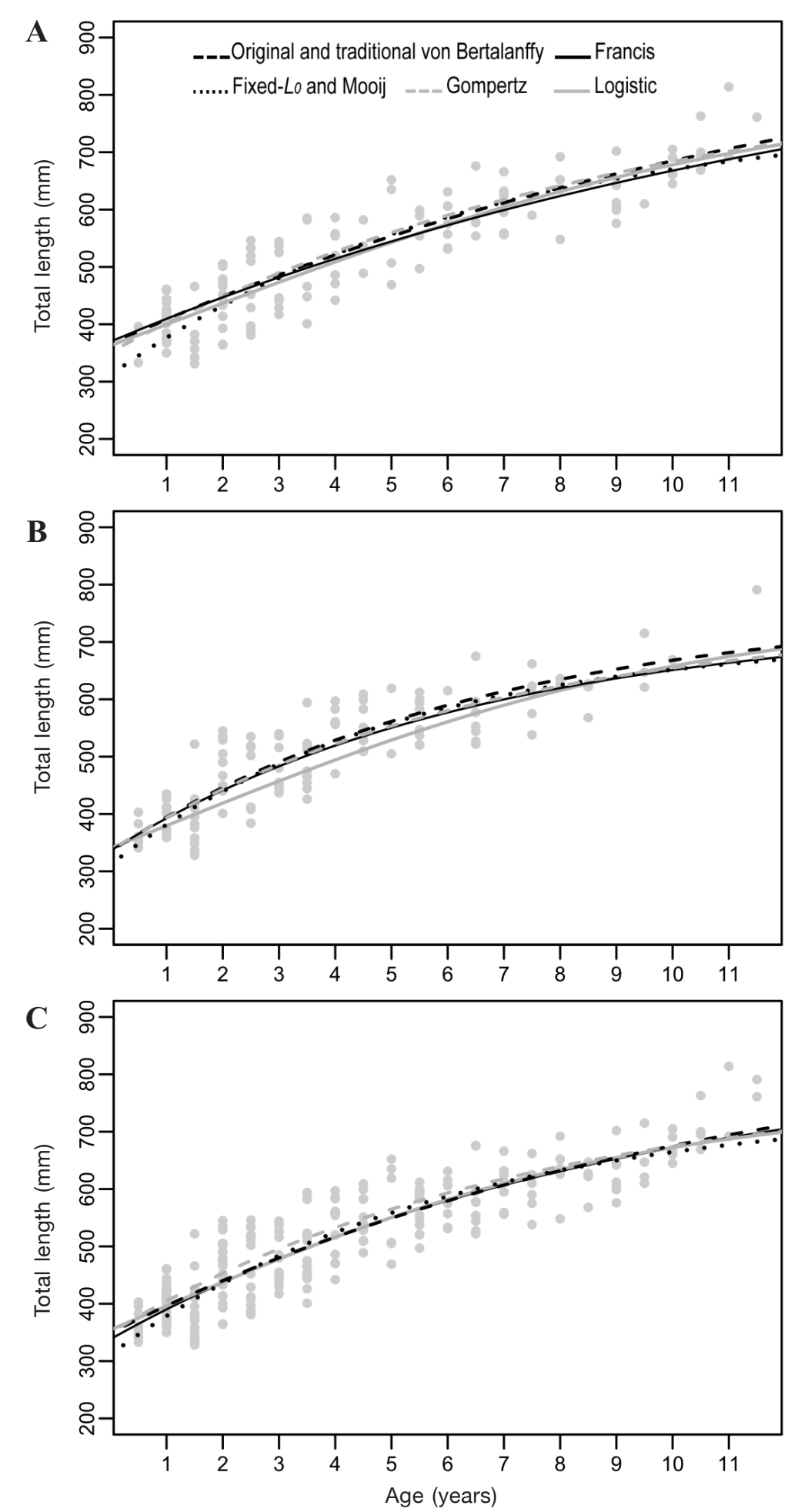

Figure 6

Growth curves for (A) females, (B) males, and (C) the entire sample of narrownose smooth-hound (Mustelus schmitti) captured in Anegada Bay, Argentina, in 2008. Black dots indicate data points for females and males. Note that curves for the original and traditional VBGF models and for the fixed- $L_{0}$ variant and the model with the Mooij parameterization are identical; therefore, each pair has only one type of line. values of the means from the observational data, back-calculated lengths were higher than the observed lengths (i.e., a slight positive Lee phenomenon occurred in the data). This trend was more evident for females than for males.

The 7 growth models used to determine the growth parameters of narrownose smooth-hound fitted the age data adequately (Fig. 6, A and B). For females, the original and traditional VBGF, Francis parameterization ( $L_{\infty}=888.93$, calculated from $L_{1}, L_{2}$, and $L_{3}$ ), and Gompertz models provided somewhat similar estimates for $L_{\infty}$. In comparison with results from those models, $L_{\infty}$ from the fixed- $L_{0}$ variant and the model with the Mooij function were lower, and the logistic model provided an intermediate estimate of $L_{\infty}$. For males, the situation was analogous; however, $L_{\infty}$ from the logistic model was similar to the values of $L_{\infty}$ estimated by the original and traditional VBGF, Francis parameterization $\left(L_{\infty}=748.05\right.$, calculated from $L_{1}, L_{2}$, and $L_{3}$ ), and Gompertz models. These parameter estimates are shown in Table 3. Back-calculated data fitted to the growth functions that were employed produced results similar to those obtained from the observational data. It is worth noting that, for females, the estimates for $L_{\infty}$ were lower than those obtained from the observational data, but, for males, this pattern was not observed (Table 3 ).

For females, the original and traditional VBGF variants and the model with the Francis parameterization of the VBGF produced the smallest AIC and $\mathrm{BIC}$ values and the highest Akaike weight of evidence ( $w$, the conditional probability of each model); when combined, these 3 growth models represented more than $65 \%$ of the weight of evidence (Table 4). The Gompertz model ranked second with a $w$ of 0.17 for females. The fixed- $L_{0}$ VBGF variant and the model with the Mooij parameterization of the VBGF produced higher values of AIC and BIC and a low $w$ for females. For males, the fixed- $L_{0}$ variant and the model with the Mooij parameterization had the lowest AIC and BIC values and high $w$. Although the original and traditional variants and the model with the Francis parameterization ranked second, they account for much of the combined $w$. All model 
Table 3

Mean estimates, observed and back calculated (BC) with standard errors (SEs), of growth parameters for the narrownose smooth-hound (Mustelus schmitti) ca ptured in Anegada Bay, Argentina, in 2008, determined with the 7 growth models. VBGF =the von Bertalanfy growth function; $L_{1}=$ length at age $1 ; L_{2}=$ the length at an age between 1 and the maximum age recorded; $L_{3}=$ length at maximum age recorded, $L_{\infty}=$ the asymptotic length; and $K, g, G$, and $G_{\text {init }}=$ the growth coefficients of the different models. Lengths are given as total lengths in centimeters.

\begin{tabular}{|c|c|c|c|c|c|c|c|c|c|c|c|c|c|}
\hline \multirow[b]{2}{*}{ Growth model } & & \multicolumn{3}{|c|}{ Females } & \multicolumn{4}{|c|}{ Males } & \multicolumn{5}{|c|}{ Sexes combined } \\
\hline & & $\begin{array}{l}\text { Observed } \\
\text { estimate }\end{array}$ & $\mathrm{SE}$ & $\begin{array}{c}\mathrm{BC} \\
\text { estimate }\end{array}$ & $\begin{array}{l}\mathrm{BC} \\
\mathrm{SE}\end{array}$ & $\begin{array}{l}\text { Observed } \\
\text { estimate }\end{array}$ & $\mathrm{SE}$ & $\begin{array}{c}\mathrm{BC} \\
\text { estimate }\end{array}$ & $\begin{array}{l}\mathrm{BC} \\
\mathrm{SE}\end{array}$ & $\begin{array}{l}\text { Observed } \\
\text { estimate }\end{array}$ & $\mathrm{SE}$ & $\begin{array}{c}\mathrm{BC} \\
\text { estimate }\end{array}$ & $\begin{array}{l}\mathrm{BC} \\
\mathrm{SE}\end{array}$ \\
\hline \multirow{3}{*}{ Original VBGF } & $L_{\infty}$ & 893.71 & 109.23 & 864.89 & 33.01 & 762.56 & 72.15 & 786.43 & 62.55 & 855.14 & 77.52 & 878.81 & 13.80 \\
\hline & $L_{0}$ & 365.96 & 13.34 & 387.78 & 9.14 & 334.58 & 16.21 & 390.35 & 9.53 & 342.89 & 10.53 & 370.63 & 2.97 \\
\hline & $K$ & 0.061 & 0.036 & 0.166 & 0.028 & 0.151 & 0.047 & 0.137 & 0.036 & 0.104 & 0.026 & $5 \quad 0.150$ & 0.014 \\
\hline \multirow[t]{3}{*}{ Traditional VBGF } & $L_{\infty}$ & 893.73 & 109.23 & 864.88 & 33.01 & 762.56 & 72.16 & 786.43 & 62.55 & 855.14 & 77.52 & 878.81 & 13.80 \\
\hline & $K$ & 0.061 & 0.036 & 0.166 & 0.028 & 0.151 & 0.047 & 0.137 & 0.036 & 0.104 & 0.026 & 0.150 & 0.014 \\
\hline & $t_{0}$ & -6.95 & 1.93 & -4.26 & 0.60 & -3.82 & 0.92 & -5.02 & 0.92 & -4.93 & 0.83 & -4.60 & 0.19 \\
\hline \multirow[t]{2}{*}{ Fixed- $L_{0}$ VBGF } & $L_{\infty}$ & 765.81 & 34.80 & 718.31 & 13.51 & 710.39 & 33.45 & 702.44 & 18.66 & 745.20 & 24.04 & 758.38 & 6.36 \\
\hline & $K$ & 0.160 & 0.024 & 0.217 & 0.019 & 0.190 & 0.030 & 0.340 & 0.025 & 0.169 & 0.016 & 0.174 & 0.016 \\
\hline \multirow[t]{3}{*}{ Francis } & $L_{1}$ & 365.96 & 13.34 & 387.78 & 9.14 & 334.58 & 16.21 & 390.35 & 9.53 & 342.89 & 10.53 & 373.36 & 6.58 \\
\hline & $L_{2}$ & 564.92 & 7.17 & 613.59 & 3.28 & 578.09 & 6.89 & 599.62 & 4.06 & 573.34 & 4.70 & 608.32 & 2.55 \\
\hline & $L_{3}$ & 706.33 & 15.43 & 704.18 & 10.79 & 683.05 & 21.78 & 698.32 & 16.49 & 700.12 & 12.12 & 704.26 & 9.09 \\
\hline \multirow[t]{2}{*}{ Mooij } & $L_{\infty}$ & 765.81 & 34.80 & 718.31 & 13.51 & 710.39 & 33.45 & 702.44 & 18.66 & 745.20 & 24.04 & 758.38 & 6.36 \\
\hline & $G_{\text {init }}$ & 119.31 & 10.72 & 162.80 & 8.47 & 137.22 & 13.65 & 155.10 & 10.48 & 125.62 & 8.16 & 146.45 & 7.70 \\
\hline \multirow[t]{3}{*}{ Gompertz } & $L_{\infty}$ & 862.53 & 102.37 & 840.93 & 24.81 & 742.70 & 43.51 & 751.05 & 44.11 & 788.81 & 47.01 & 749.33 & 22.76 \\
\hline & $G$ & -0.13 & 0.11 & -0.46 & 0.04 & -0.28 & 0.06 & -0.44 & 0.07 & -0.20 & 0.06 & -0.44 & 0.04 \\
\hline & $t$ & 0.13 & 0.04 & 0.22 & 0.03 & 0.22 & 0.05 & 0.19 & 0.04 & 0.16 & 0.03 & 0.21 & 0.02 \\
\hline \multirow[t]{3}{*}{ Logistic } & $L_{\infty}$ & 815.52 & 51.93 & 777.30 & 8.38 & 758.68 & 51.94 & 757.36 & 11.37 & 753.75 & 34.22 & 730.46 & 18.14 \\
\hline & $L_{0}$ & 362.80 & 11.73 & 382.14 & 8.86 & 340.32 & 13.24 & 398.74 & 7.87 & 354.13 & 8.64 & 398.88 & 5.36 \\
\hline & $g$ & 0.182 & 0.020 & 0.406 & 0.018 & 0.208 & 0.027 & 0.402 & 0.023 & 0.223 & 0.028 & $\quad 0.260$ & 0.023 \\
\hline
\end{tabular}

curves fitted to the growth data can be observed in Figure $6 \mathrm{~A}$ for females and $6 \mathrm{~B}$ for males. Note that the original and traditional VBGF variants and the model with the Francis parameterization of the VBGF have the exact same AIC and BIC values because they are algorithmic modifications of the same model; hence, AIC and BIC values will not change. The same is true for the fixed- $L_{0}$ variant and the model with the Mooij parameterization of the VBGF.

We chose to use the original VBGF model in our comparisons of growth between sexes for narrownose smooth-hound. The likelihood ratio test for the original VBGF model revealed no significant differences in growth between sexes for each parameter (mean $\chi^{2}$ : 1.94 [SE 0.22]; $P>0.15$ ). Extra sum-of-squares tests produced a similar result, failing to identify any differences in the growth parameters between sexes (mean $F=1.28$ [SE 0.51]; $P>0.15$ ). The AIC, BIC, and $w$ values presented in Table 5 also indicate that there were no differences between sexes in growth parameters. For females and males combined, estimates of the growth parameters from the 7 growth models are shown in Table 3, with the corresponding fitted growth curve shown in Figure 6C.

The overall $\phi$, calculated by using the parameters of the original VBGF model, was 4.69 for females and 4.94 for males.
Longevity was 20.87 years and 12.24 years for females and males, respectively. Total natural mortality rates were 0.19/year and 0.26/year for females and males, respectively.

\section{Discussion}

Age and growth estimates for fish have been shown to be highly dependent on the size range of collected samples (Campana, 2001). For example, Lessa et al. (2016) in their study of the crocodile shark (Pseudocarcharias kamoharai) did not capture small individuals, and the lack of small fish introduced a bias in their estimates of the growth parameters. This bias makes their results applicable to only the study area or appropriate for extrapolation only for populations with a similar size composition. In long-lived species >30 years, e.g. Lamniformes like the white shark (Carcharodon carcharias), or the shortfin mako (Isurus oxyrinchus), the lack of larger individuals in a sample can result in an underestimation of maximum age (Ardizzone et al., 2006; Natanson et al., 2006; Hamady et al., 2014; Andrews and Kerr, 2015). In our study of narrownose smooth-hound, the size of individuals captured ranged from $300 \mathrm{~mm}$ TL up to $810 \mathrm{~mm}$ TL; in other studies, individuals $>850 \mathrm{~mm}$ TL, when present, have not been 


\section{Table 4}

Akaike and Bayesian information criterion (AIC and BIC) values and Akaike weight of evidence $(w)$ for the 7 growth models applied to the age data of the narrownose smooth-hound (Mustelus schmitti) captured in 2008 in Anegada Bay, Argentina. VBGF=von Bertalanfy growth function.

\begin{tabular}{lccccccc}
\hline & \multicolumn{3}{c}{ Females } & & \multicolumn{3}{c}{ Males } \\
\cline { 2 - 3 } \cline { 7 - 8 } Growth model & AIC & BIC & $w$ & & AIC & BIC & $w$ \\
\hline Original VBGF & 1396.4 & 1407.9 & 0.22 & & 1213.5 & 1224.4 & 0.14 \\
Traditional VBGF & 1396.4 & 1407.9 & 0.22 & & 1213.5 & 1224.4 & 0.14 \\
Fixed- $L_{0}$ VBGF & 1401.6 & 1410.3 & 0.02 & & 1212.4 & 1220.6 & 0.24 \\
Francis & 1396.4 & 1407.9 & 0.22 & & 1213.5 & 1224.4 & 0.14 \\
Mooij & 1401.6 & 1410.3 & 0.02 & & 1212.4 & 1220.6 & 0.24 \\
Gompertz & 1396.9 & 1408.4 & 0.17 & 1214.9 & 1225.8 & 0.07 \\
Logistic & 1397.5 & 1409.0 & 0.13 & 1216.3 & 1227.2 & 0.03 \\
& & & & & & & \\
\hline
\end{tabular}

abundant (Menni, 1985; López Cazorla, 1987; Batista, 1988; Massa and Lasta ${ }^{2}$; Hozbor et. al. ${ }^{6}$ ). Some authors have reported maximum sizes for this species of up to $1020 \mathrm{~mm} \mathrm{TL}$, but fish in their studies were found in populations that inhabited open waters (Hozbor et al. ${ }^{6}$ ); all published studies conducted on populations inhabiting the coastal areas of Argentina have reported size ranges similar to those of our study (Chiaramonte and Pettovello, 2000; Sidders et al., 2005; Segura and Milessi, 2009). It is because of this similarity in size ranges that we consider our findings representative

\section{Table 5}

Akaike and Bayesian information criterion (AIC and BIC) values and Akaike weight of evidence $(w)$ for 8 different versions of the original von Bertalanffy growth function model used for the comparison of growth between sexes: $L_{\infty}, L_{0}, K$, the growth model where $L_{\infty}, L_{0}$, and $K$ are different between sexes; $L_{\infty}, K$, the growth model where both $L_{\infty}$ and $K$ are different between sexes; $L_{\infty}, L_{0}$, the growth model where both $L_{\infty}$ and $L_{0}$ are different between sexes; $L_{0}, K$, the growth model where both $L_{0}$ and $K$ are different between sexes; only $L_{\infty}$, the growth model where only $L_{\infty}$ is different among sexes; only $K$, the growth model where only $K$ is different among sexes; only $L_{0}$, the growth model where only $L_{0}$ is different among sexes; and none, the growth model where all parameters are equal for both females and males.

\begin{tabular}{lccr}
\hline Models & AIC & BIC & \multicolumn{1}{c}{$w$} \\
\hline$L_{\infty}, L_{0}, K$ & 2607.85 & 2632.36 & $<0.001$ \\
$L_{\infty}, K$ & 2607.29 & 2628.30 & 0.005 \\
$L_{\infty}, L_{0}$ & 2607.89 & 2628.89 & 0.003 \\
$L_{0}, K$ & 2607.83 & 2628.84 & 0.004 \\
Only $L_{\infty}$ & 2605.89 & 2623.40 & 0.053 \\
Only $K$ & 2605.88 & 2623.39 & 0.053 \\
Only $L_{0}$ & 2605.89 & 2623.39 & 0.053 \\
None & 2603.89 & 2617.90 & 0.829 \\
& & & \\
\hline
\end{tabular}

of and applicable to other coastal populations of narrownose smooth-hound.

Another important aspect of any age and growth study on fish is verification of the estimated parameters (Goldman et al., 2012). Verification of estimated age and growth parameters have been undertaken for several species of the Mustelus genus (i.e., Cailliet et al., 1990; Yudin and Cailliet, 1990; Moulton et al., 1992; Goosen and Smale, 1997; Farrell et al., 2010). This genus deposits growth bands annually, and the deposition of translucent bands occurs during summer-autumn (Cailliet et al., 1990; Yudin and Cailliet, 1990; Moulton et al., 1992; Goosen and Smale, 1997; Farrell et al., 2010); our results on narrownose smooth-hound correspond with this finding. Moreover, the associated notching pattern observed in our study was similar to patterns reported for other species of Mustelus (i.e., Moulton et al., 1992; Conrath et al., 2002; Farrell et al., 2010). The precision in interpreting these growth bands was also high between readers and within readers, providing confidence in the reproducibility of our results. The lack of an adequate number of older sharks in our sample might have led to an underestimation of $L_{\infty}$; however, the similarity of estimates between our observational data and the back-calculated data fortunately indicates that our sample size was adequate. The lower SE values for the back calculations, compared with the SE values for the observational data, indicate that these calculations may accurately reflect the growth parameters for narrownose smooth-hound. Nevertheless, it is important to note that for back-calculated results, it is assumed that growth is constant and does not change over time (Goldman et al., 2012).

The maximum age determined for narrownose smooth-hound in our study is similar to ages reported for some species of Mustelus (Cailliet et al., 1990; Yudin and Cailliet, 1990; Farrell et al., 2010) and is lower than age ranges determined for larger Mustelus species (Yudin and Cailliet, 1990; Moulton et al., 1992; Goosen and Smale, 1997; Conrath et al., 2002; Farrell et al., 


\section{Table 6}

Size range (total lengths in millimeters), maximum age measured $\left(t_{\max }\right)$, asymptotic length $\left(L_{\infty}\right)$, and growth coefficient $(K)$ of the von Bertalanffy growth function and growth performance index ( $\phi$ ) for 9 species of the Mustelus genus from this study and other studies.

\begin{tabular}{llrrrrl}
\hline Species & $\begin{array}{c}\text { Size range } \\
\text { (mm TL) }\end{array}$ & $t_{\text {max }}$ & $L_{\infty}$ & $K$ & $\phi$ & Main reference \\
\hline Mustelus schmitti & $300-810$ & 11 & 894 & 0.06 & 4.69 & This study \\
Mustelus schmitti & $390-950$ & 16 & 1000 & 0.10 & 5.00 & Hozbor et al. $^{6}$ \\
Mustelus schmitti & $250-960$ & 14 & 1028 & 0.08 & 4.92 & Batista, 1988 \\
Mustelus antarcticus & $600-1700$ & 16 & 2000 & 0.12 & 5.68 & Moulton et al., 1992 \\
Mustelus californicus & $235-1250$ & 9 & 1500 & 0.17 & 5.58 & Yudin and Cailliet, 1990 \\
Mustelus henlei & $257-1000$ & 13 & 1000 & 0.22 & 5.34 & Yudin and Cailliet, 1990 \\
Mustelus manazo & $680-800$ & 10 & 2000 & 0.10 & 5.60 & Cailliet et al., 1990 \\
Mustelus mustelus & $360-1640$ & 24 & 2000 & 0.07 & 5.44 & Goosen and Smale, 1997 \\
Mustelus walkeri & $410-1050$ & 16 & 2000 & 0.07 & 5.44 & Rigby et al., 2016 \\
Mustelus asterias & $440-1120$ & 13 & 1000 & 0.19 & 5.27 & Farrell et al., 2010 \\
Mustelus canis & $330-1320$ & 16 & 1200 & 0.29 & 5.62 & Conrath et al., 2002 \\
& & & & & & \\
\end{tabular}

2010; Rigby et al., 2016) (Table 6). To date, only one technical report and a M.S. thesis have described the age of narrownose smooth-hound (Batista, 1988; Hozbor et al. ${ }^{6}$ ), and both of these publications report on studies that included in their sampling fish older than the fish that we captured (Table 6). It is likely that the larger and older fish in the Hozbor et al. ${ }^{6}$ and $\mathrm{Ba}$ tista (1988) studies account for the differences in range of ages between our study and theirs. The results of Hozbor et al. ${ }^{6}$ are consistent with our results for the mean lengths at age for ages below 5 years, but, for animals $>5$ years, they report larger sizes at age. Batista's (1988) mean lengths at age, however, are greater than our estimations for almost all ages, but he did not provide length at age for age 0 and 1 and did not capture males older than 7 years, which makes throughout comparisons difficult.

In the population of narrownose smooth-hound in Anegada Bay, the rate of growth reflected in the increments in the mean length at age was not consistent for some ages. A similar phenomenon was reported by Hozbor et al. ${ }^{6}$ and Batista (1988), as well as in studies of other shark species (Cailliet et al., 1990, Goldman et al., 2006, Farrel et al., 2010, Fernandez-Carvalho et al., 2015). In a number of other studies on the age and growth of elasmobranches, tables of length at age are not presented (e.g., Kusher et al., 1992; Goosen and Smale, 1997; Smith et al., 2003, 2007; McFarlane and King, 2006; Booth et al., 2011; Joung et al., 2016; Lessa et al., 2016); therefore, it is difficult to determine whether this phenomenon is more or less universal for elasmobranchs or restricted to certain species.

The narrownose smooth-hound attains an appreciably smaller $L_{\infty}$ and $K$ than other representatives of the Mustelus genus, with the exception of the starspotted smooth-hound (M. manazo) (Yudin and Cailliet, 1990; Table 6). In comparison with values reported by $\mathrm{Ba}-$ tista (1988) and Hozbor et al. ${ }^{6}$, who also worked with narrownose smooth-hound, values of $L_{\infty}$ and $K$ from our study were also much lower. A possible explanation for this result is that the overall size distribution of the samples used by Batista (1988) and Hozbor et al. ${ }^{6}$ included many large individuals (>850 $\mathrm{mm}$ TL), which were not present in our study, and only a low number of small individuals ( $<400 \mathrm{~mm}$ TL) both of which had a consequent effect on the asymptotic behavior of the VBGF. In these 2 studies, more than $60 \%$ of the individuals were larger than $600 \mathrm{~mm}$ TL, but samples in our study only $20 \%$ of individuals were above that TL. As Campana (2001) points out, skewed size distributions can introduce bias in age estimates, and differences in size distributions between studies can accentuate such differences.

Differences in the estimations of $L_{\infty}$ and $K$ can also arise from differences in the aging techniques employed. Whereas Batista (1988) used whole vertebra and Hozbor et al. ${ }^{6}$ employed sectioned vertebra, we used thinly sectioned slices. Despite their use of theoretically more imprecise vertebra preparations, these authors could identify ages >than 11 years with their methods, indicating that the use of whole vertebrae by Batista (1988) or sectioned vertebrae by Hozbor et al. ${ }^{6}$ could be useful enough to study age for this species.

Another possible explanation is the difference in the period of sampling. Hozbor et al. ${ }^{6}$ sampled during 2003-2004, almost 5 years before our research. Given the high level of fishing effort exerted on this species between 2004 and 2010 (Massa et al., 2006; Fernández Aráoz et $a .^{8}$ ), it is possible that natural populations experienced a reduction in their maximum length be-

\footnotetext{
${ }^{8}$ Fernández Aráoz, N. C., A. N. Lagos, and C. R. Carozza. 2009. Asociación íctica costera bonaerense 'variado costero' capturas declaradas por la flota comercial Argentina durante el año 2008. INIDEP Inf. Tec. Of. 31, 26 p. [Available from website.]
} 
cause larger fish are most likely to be captured first (Beverton and Holt, 1957; Hilborn, 1992). In the case of Batista (1988), sampling was conducted almost 30 years ago, before the considerable increase in fishing effort and capture that took place in Brazil that ultimately produced a decline in populations of narrownose smooth-hound as predicted by Haimovici (1997).

The explanation outlined in the previous paragraph is also supported by the difference observed in the mean length at age calculated in each study. In Hozbor et al. ${ }^{6}$, fish with ages above 5 years had lengths that were larger by a mean of $68.8 \mathrm{~mm}$ and $64.1 \mathrm{~mm}$ TL for males and females, respectively, than the lengths in our study. Batista (1988) presents even greater differences, with fish up to $80 \mathrm{~mm}$ TL larger than the fish in our study. It is likely that the largest and oldest specimens present in the populations sampled by Hozbor et al. ${ }^{6}$ and Batista (1988) were not present in the population we sampled because they would have been removed by fishing, and their absence from our sample, therefore, potentially influenced the estimate of $L_{\infty}$ that we calculated. Reduction in the length by age is a serious consequence of overfishing in all fish populations (Beverton and Holt, 1957; Murawski, 2000; Froese, 2004); therefore, if this is the case, special attention should be paid to the possibility of stock depletion by fishing in the coastal populations of narrownose smooth-hound.

Lastly, geographic location may have played a role in the differences in parameter estimates between Hozbor et al. ${ }^{6}$ and Batista (1988) and our study. The sampling area for Hozbor et al. ${ }^{6}$ extended from the Uruguayan-Argentinean common fishing zone to the open sea region of El Rincón $\left(39-41^{\circ} \mathrm{S}\right)$ in Argentina, and Batista (1988) performed his sampling on the Brazilian shelf near Rio Grande do Sul. Unfortunately, to our knowledge, biological differences between the stocks of narrownose smooth-hound of Argentina and Brazil have not been studied yet, or if they have, results remain unpublished.

Values of $\phi$ calculated for narrownose smooth-hound in our study indicate a slower rate than that of other representatives of the Mustelus genus. Results from Batista (1988) and Hozbor et al. ${ }^{6}$ indicate growth rates similar to those in our study, albeit slightly greater (Table 6). It is important to point out that despite the differences in the estimations of $L_{\infty}$ and $K$ between our study and those of Batista (1988) and Hozbor et al. ${ }^{6}$, the values of $\phi$ for this species were closer for those studies and ours than for studies of the other Mustelus species examined.

Differences in growth parameters, by sex, are commonplace with sharks, especially for viviparous species (Cortés et al., 2010), like the night shark (Carcharhinus signatus; Lessa et al., 2000), the crocodile shark (Lessa et al., 2016), and the bigeye thresher (Alopias superciliosus; Fernandez-Carvalho et al., 2015). However, there are also examples for which no differences exist between sexes, as with the sandbar shark $(C$. plumbeus; Casey et al., 1985), the oceanic whitetip shark (C. longimanus; Seki et al., 1998), the sharptooth houndshark (Triakis megalopterus; Booth et al., 2011), the bull shark (C. leucas; Neer et al., 2005), and the blue shark (Prionace glauca; Skomal and Natanson, 2003).The differences in estimated growth parameters for male and female narrownose smooth-hound, that are observed with other species, were not statistically significant in our study. Despite this lack of significant difference, males appear to grow faster in their first year $\left(G_{\text {init }}\right.$ : $137.22 \mathrm{~mm}$ TL of growth in the first year) than females $\left(G_{\text {init }}: 119.31 \mathrm{~mm}\right.$ TL of growth in the first year), and males also reach a higher TL at half $t_{\max }$ $\left(L_{2}: 578.09 \mathrm{~mm} \mathrm{TL}\right)$ than that of females $\left(L_{2}: 564.92\right.$ $\mathrm{mm}$ TL), and females attain a larger $L_{\infty}$. These types of differences have been reported recently for the closely related species, the eastern spotted gummy shark ( $M$. walkeri; Rigby et al., 2016).

Successful and sustainable management of any fishery is based on robust and accurate estimates of growth, which in turn are dependent on quality age and growth studies (Fernandez-Carvalho et al., 2015). Therefore, it is essential to improve science-based fishery data. The narrownose smooth-hound of Anegada Bay has a relatively fast growth in its initial year of life, reaching a length of approximately $400 \mathrm{~mm}$ TL. Growth slows down in subsequent years, and, according to our results, length at first maturity (546 and $563 \mathrm{~mm}$ TL for males and females respectively; Colautti et al., 2010) is reached at an age of 7.61 years for females and 6.79 years for males. These values represent a maturation rate comparable to that of other species of Mustelus; for example, the eastern spotted gummy shark matures at an age around 7-9 years and at a length of 670 to $800 \mathrm{~mm}$ TL (Rigby et al., 2016).

This late age at first maturity of the narrownose smooth-hound is indicative of a high susceptibility to fishery-induced mortality and highlights the importance of conservation for the slow-maturing species in this genus. Consequently, narrownose smooth-hound individuals of $600 \mathrm{~mm}$ TL or less should be excluded from catches of commercial fisheries, an approach that would mean excluding sharks younger than, approximately, 7 years. Despite the relatively high rate of estimated natural mortality, modeling results indicate that protection of old adults is more appropriate than protection of juveniles in the case of shark fisheries (Prince, 2005). Whether this importance of protecting old adults applies to narrownose smooth-hound (or any other small triakid sharks) has yet to be evaluated and warrants further research.

The slow growth and late age at maturity (for fishing purposes) of the narrownose smooth-hound reported here indicate that this species is vulnerable to overexploitation and that the population studied may have signs of having been deeply affected. Ensuring both a sustainable population and fishery of this species requires management coordinated with a strong foundation on science-based studies for the entire distribution range of this species. 


\section{Acknowledgments}

The financial support provided by Consejo Nacional de Investigaciones Científicas y Técnicas, Agencia Nacional de Promoción Científica y Tecnológica (project PAE 22666/0), and Universidad Nacional del Sur (project PGI 24/191) is gratefully acknowledged. We also thank N. Hozbor (Instituto Nacional de Investigación y Desarrollo Pesquero), who showed us preparation and observation techniques, and staff at the Laboratorio de Petrotomia (Universidad Nacional del Sur) for their generous assistance in vertebral inclusion.

\section{Literature cited}

Andrews, A. H., and L. A. Kerr.

2015. Validated age estimates for large white sharks of the northeastern Pacific Ocean: altered perceptions of vertebral growth shed light on complicated bomb $\Delta^{14} \mathrm{C}$ results. Environ. Biol. Fish. 98:971-978. Article

Ardizzone, D., G. M. Cailliet, L. J. Natanson, A. H. Andrews, L. A. Kerr, and T. A. Brown.

2006. Application of bomb radiocarbon chronologies to shortfin mako (Isurus oxyrinchus) age validation. Environ. Biol. Fish. 77:355-366. Article

Barker, M. J., and V. Schluessel.

2005. Managing global shark fisheries: suggestions for prioritizing management strategies. Aquat. Conserv. 15:325-347. Article

Batista, V. S.

1988. Determinação de idade e análise do crescimento do cação Mustelus schmitti Springer 1939 (Elasmobranchii, Triakidae) da plataforma continental do Rio Grande do Sul. M.S. thesis, 99 p. Universidade Federal do Rio Grande, Rio Grande, Brazil.

Beamish, R. J., and D. A. Fournier.

1981. A method for comparing the precision of a set of age determinations. Can. J. Fish. Aquat. Sci. 38:982983. Article

Beverton, R. J. H., and S. J. Holt.

1957. On the dynamics of exploited fish populations. Fish. Invest. Ser. II, vol. 19, 533 p. Her Majesty's Stationery Office, London.

Booth, A. J., A. J. Foulis, and M. J. Smale.

2011. Age validation, growth, mortality, and demographic modeling of spotted gully shark (Triakis megalopterus) from the southeast coast of South Africa. Fish. Bull. 109:101-112.

Burnham, K. P., and D. R. Anderson.

2002. Model selection and multimodel inference: a practical information-theoretic approach, $2^{\text {nd }}$ ed., $488 \mathrm{p}$. Springer-Verlag, New York.

Cailliet, G. M.

1990. Elasmobranch age determination and verification: an updated review. In Elasmobranchs as living resources: advances in the biology, ecology, systematics, and the status of the fisheries (H. L. Pratt Jr., S. H. Gruber, and T. Taniuchi, eds.), p. 157-165. NOAA Tech. Rep. NMFS 90.

Cailliet, G. M., K. G. Yudin, S. Tanaka, and T. Taniuchi.

1990. Growth characteristics of two populations of Mustelus manazo from Japan based upon cross-readings of vertebral bands. In Elasmobranchs as living resources: advances in the biology, ecology, systematics, and the status of the fisheries (H. L. Pratt Jr., S. H. Gruber, and T. Taniuchi, eds.), p. 167-176. NOAA Tech. Rep. NMFS 90. Cailliet, G. M., W. D. Smith, H. F. Mollet, and K. J. Goldman. 2006. Age and growth studies of chondrichthyan fishes: the need for consistency in terminology, verification, validation, and growth function fitting. Environ. Biol. Fish. 77:211-228. Article

Campana, S. E.

2001. Accuracy, precision and quality control in age determination, including a review of the use and abuse of age validation methods. J. Fish Biol. 59:197-242. Article

Campana, S. E., M. C. Annand, and J. I. McMillan.

1995. Graphical and statistical methods for determining the consistency of age determinations. Trans. Am. Fish. Soc. 124:131-138. Article

Casey, J. G., H. L. Pratt Jr, and C. E Stillwell.

1985. Age and growth of the sandbar shark (Carcharhinus plumbeus) from the western North Atlantic. Can. J. Fish. Aquat. Sci. 42:963-975. Article

Chang, W. Y. B.

1982. A statistical method for evaluating the reproducibility of age-determination. Can. J. Fish. Aquat. Sci. 39:1208-1210. Article

Chiaramonte, G. E., and A. D. Pettovello.

2000. The biology of Mustelus schmitti in southern Patagonia, Argentina. J. Fish Biol. 57:930-942. Article

Chugunova, N. I.

1963. Age and growth studies in fish; a systematic guide for ichthyologists, 132 p. Israel Program for Scientific Translations, Jerusalem, Israel. [Translated from Russian.]

Colautti, D., C. Baigun, A. Lopez Cazorla, F. Llompart, J. M. Molina, P. Suquele, and S. Calvo.

2010. Population biology and fishery characteristics of the smooth-hound Mustelus schmitti in Anegada Bay, Argentina. Fish. Res. 106:351-357. Article

Conrath, C. L.

2005. Reproductive biology. In Management techniques for elasmobranch fisheries (J. A. Musick and R. Bonfil, eds.), p. 103-126. FAO Fish. Tech. Pap. 474. FAO, Rome.

Conrath, C. L., J. Gelsleichter, and J. A. Musick.

2002. Age and growth of the smooth dogfish (Mustelus canis) in the northwest Atlantic Ocean. Fish. Bull. 100:674-682.

Cortés, E., F. Arocha, L. Beerkircher, F. Carvalho, A. Domingo, M. Heupel, H. Holtzhausen, M. N. Santos, M. Ribera, and C. Simpfendorfer.

2010. Ecological risk assessment of pelagic sharks caught in Atlantic pelagic longline fisheries. Aquat. Living Resour. 23:25-34. Article

Dulvy, K. N., J. K. Baum, S. Clarke, L. J. V. Compagno, E. Cortés, A. Domingo, S. Fordham, S. Fowler, M. P. Francis, C. Gibson, et al.

2008. You can swim but you can't hide: the global status and conservation of oceanic pelagic sharks and rays. Aquat. Conserv. 482:459-482. Article

Fabens, A. J.

1965. Properties and fitting of the von Bertalanffy growth curve. Growth 29:265-289.

Farrell, E. D., S. Mariani, and M. W. Clarke.

2010. Age and growth estimates for the starry smoothhound (Mustelus asterias) in the Northeast Atlantic Ocean. ICES J. Mar. Sci. 67:931-939. Article 
Fernandez-Carvalho, J., R. Coelho, J. Mejuto, E. Cortés, A. Domingo, K. Yokawa, K.-M. Liu, B. García-Cortés, R. Forselledo, S. Ohshimo, et al.

2015. Pan-Atlantic distribution patterns and reproductive biology of the bigeye thresher, Alopias superciliosus. Rev. Fish Biol. Fish. 25:551-568. Article

Figueiredo, J. L.

1977. Manual de peixes marinhos do sudeste do Brasil. I. Introdução. Cações, raias e quimeras, 104 p. Museu de Zoologia, Univ. São Paulo, São Paulo, Brazil.

Francis, R. I. C. C.

1988. Are growth parameters estimated from tagging and age-length data comparable? Can. J. Fish. Aquat. Sci. 45:936-942. Article

Froese, R.

2004. Keep it simple: three indicators to deal with overfishing. Fish Fish. 5:86-91. Article

Gompertz, B.

1825. On the nature of the function expressive of the law of human mortality, and on a new mode of determining the value of life contingencies. Philos. Trans. R. Soc. Lond. 115:513-583.

Goldman, K. J., S. Branstetter, and J. A. Musick.

2006. A re-examination of the age and growth of sand tiger sharks, Carcharias taurus, in the western North Atlantic: the importance of ageing protocols and use of multiple back-calculation techniques. In Age and growth of chondrichthyan fishes: new methods, techniques and analysis (J. K. Carlson and K. J. Goldman, eds.), p. 241-252. Springer, Dordrecht, Netherlands.

Goldman, K. J., G. M. Cailliet, A. H. Andrews, and L. J. Natanson.

2012. Assessing the age and growth of chondrichthyan fishes. In Biology of sharks and their relatives, 2nd ed. (J. C. Carrier, J. A. Musick, and M. R. Heithaus, eds.), p. 423-452. CRC Press, Boca Raton, FL.

Goosen, A. J. J., and M. J. Smale.

1997. A preliminary study of age and growth of the smoothhound shark Mustelus mustelus (Triakidae). S. Afr. J. Mar. Sci. 18:85-92. Article

Haimovici, M.

1997. Recursos pesqueiros demersais da regiao sul, 80 p. Fundação dos Estudos do Mar, Rio de Janeiro, Brazil.

Hamady, L. L., L. J. Natanson, G. B. Skomal, and S. R. Thorrold.

2014. Vertebral bomb radiocarbon suggests extreme longevity in white sharks. PLoS ONE 9: e84006. Article

Hilborn, R.

1992. Can fisheries agencies learn from experience? Fisheries 17:6-14. Article

Hoenig, J. M.

1983. Empirical use of longevity data to estimate mortality rates. Fish. Bull. 82:898-903.

Jensen, A. L.

1996. Beverton and Holt life history invariants result from optimal trade-off of reproduction and survival. Can. J. Fish. Aquat. Sci. 53:820-822. Article

Joung, S.-J., C.-C. Chen, K.-M. Liu and T.-C. Hsieh.

2016. Age and growth estimates of the Kwangtung skate Dipturus kwangtungensis in the waters of northern Taiwan. J. Mar. Biol. Assoc. U.K. 96:1-8. Article

Katsanevakis, S.

2006. Modelling fish growth: model selection, multi-model inference and model selection uncertainty. Fish. Res. 81:229-235. Article
Katsanevakis, S., and C. D. Maravelias.

2008. Modelling fish growth: multi-model inference as a better alternative to a priori using von Bertalanffy equation. Fish Fish. 9:178-187. Article

Kimura, D. K.

1980. Likelihood methods for the von Bertalanffy growth curve. Fish. Bull. 77:765-776.

Kusher, D. I., S. E. Smith, and G. M. Cailliet.

1992. Validated age and growth of the leopard shark, Triakis semifasciata, with comments on reproduction. Environ. Biol. Fish. 35:187-203. Article

Lessa, R., F. M. Santana, V. Batista, and Z. Almeida.

2000. Age and growth of the daggernose shark Isogomphodon oxyrhynchus, from northern Brazil. Mar. Freshw. Res. 51:339-347. Article

Lessa, R., H. A. Andrade, K. L. De Lima, and F. M. Santana. 2016. Age and growth of the midwater crocodile shark Pseudocarcharias kamoharai. J. Fish Biol. Article

Lopez Cazorla, A. C.

1987. Contribución al conocimiento de la ictiofauna marina del área de Bahía Blanca. Ph.D. diss., 247 p. Univ. Nac. La Plata, La Plata, Argentina.

Lopez Cazorla, A., J. M. Molina, and C. Ruarte.

2014. The artisanal fishery of Cynoscion guatucupa in Argentina: exploring the possible causes of the collapse in Bahía Blanca estuary. J. Sea Res. 88:29-35. Article

Massa, A., N. Hozbor, G. E. Chiaramonte, A. D. Balestra, and C. M. Vooren.

2006. Mustelus schmitti. The IUCN Red List of Threatened Species 2006: e.T60203A12318268. Article

McFarlane, G. A., and J. R. King.

2006. Age and growth of big skate (Raja binoculata) and longnose skate (Raja rhina) in British Columbia waters. Fish. Res. 78:169-178. Article

Menni, R. C.

1985. Distribución y biología de Squalus acanthias, Mustelus schmitti y Galeorhinus vitaminicus en el Mar Argentino en agosto-setiembre de 1978 (Chondrichthyes) Rev. Mus. La Plata Nueva Ser. Secc. Zool. 13:151-182.

Menni, R. C., M. B. Cousseau, and A. R. Gosztonyi.

1986. Sobre la biología de los tiburones costeros de la Provincia de Buenos Aires. An. Soc. Cient. Argent. 213:3-27.

Methot, R. D., Jr., and C. R. Wetzel.

2013. Stock synthesis: a biological and statistical framework for fish stock assessment and fishery management. Fish. Res. 142:86-99. Article

Molina, J. M.

2013. La comunidad íctica de Bahía Anegada: estructura, composición, dinámica estacional y aspectos biológicos. Ph.D. diss., 234 p. Univ. Nac. Sur, Bahía Blanca, Argentina.

Molina, J. M., and A. Lopez Cazorla.

2011. Trophic ecology of Mustelus schmitti (Springer, 1939) in a nursery area of northern Patagonia. J. Sea Res. 65:381-389. Article

Molina, J. M., and S. J. Cooke.

2012. Trends in shark bycatch research: current status and research needs. Rev. Fish Biol. Fish. 22:719-737. Article

Mooij, W. M., J. M. Van Rooij, and S. Wijnhoven.

1999. Analysis and comparison of fish growth from small samples of length-at-age data: detection of sexual dimorphism in Eurasian perch as an example. Trans. Am. Fish. Soc. 128:483-490. Article 
Moulton, P. L., T. I. Walker, and S. R. Saddlier. 1992. Age and growth studies of gummy shark, Mustelus antarcticus Günther, and school shark, Galeorhinus galeus (Linnaeus), from southern Australian waters. Aust. J. Mar. Freshw. Res. 43:1241-1267. Article

Murawski, S. 2000. Definitions of overfishing from an ecosystem perspective. ICES J. Mar. Sci. 57:649-658. Article

Natanson, L. J., J. G. Casey, and N. E. Kohler.

1995. Age and growth estimates for the dusky shark, Carcharhinus obscurus, in the western North Atlantic Ocean. Fish. Bull. 93:116-126.

Natanson, L. J., N. E. Kholer, D. Ardizzone, G. M. Cailliet, S. Wintner, and H. F. Mollet.

2006. Validated age and growth estimates for the shortfin mako, Isurus oxyrinchus, in the North Atlantic Ocean. Environ. Biol. Fish. 77:367-383. Article

Neer, J. A., B. A. Thompson, and J. K. Carlson.

2005. Age and growth of Carcharhinus leucas in the northern Gulf of Mexico: incorporating variability in size at birth. J. Fish Biol. 67:370-383. Article

Officer, R. A., A. S. Gason, T. I. Walker, and J. G. Clement.

1996. Sources of variation in counts of growth increments in vertebrae from gummy shark, Mustelus antarcticus, and school shark, Galeorhinus galeus: implications for age determination. Can. J. Fish. Aquat. Sci. 53:1765-1777. Article

Ogle, D. H.

2015. Introductory fisheries analyses with $\mathrm{R}, 317 \mathrm{p}$. Chapman and Hall/CRC, Boca Raton, FL.

Pauly, D.

1980. On the interrelationships between natural mortality, growth parameters, and mean environmental temperature in 175 fish stocks. ICES J. Mar. Sci. 39:175-192. Article

1984. Recent developments in the methodology available for the assessment of exploited fish stocks of reservoirs. In Status of African reservoir fisheries. CIFA Tech. Pap. 10 (J. M. Kapetsky and T. Petr, eds.), p. 321-326. FAO, Rome.

Prince, J. D.

2005. Gauntlet fisheries for elasmobranchs-the secret of sustainable shark fisheries. J. Northwest Atl. Fish. Sci. 35:407-416

R Core Team.

2016. R: a language and environment for statistical computing. R Foundation for Statistical Computing, Vienna, Austria. [Available from website, accessed March 2016.]

Reeves, S. A.

2003. A simulation study of the implications of age-reading errors for stock assessment and management advice. ICES J. Mar. Sci. 60:314-328. Article

Ricker, W. E.

1976. Review of the rate of growth and mortality of Pacific salmon in salt water, and noncatch mortality caused by fishing. J. Fish. Board Can. 33:1483-1524. Article
Rigby, C. L., W. T. White, J. J. Smart, and C. A. Simpfendorfer. 2016. Life histories of two deep-water Australian endemic elasmobranchs: Argus skate Dipturus polyommata and eastern spotted gummy shark Mustelus walkeri. J. Fish Biol. 88:1149-1174. Article

Ritz, C., and J. C. Streibig.

2008. Nonlinear regression with R, 148 p. Springer-Verlag, New York.

Segura, A. M., and A. C. Milessi.

2009. Biological and reproductive characteristics of the Patagonian smoothhound Mustelus schmitti (Chondrichthyes, Triakidae) as documented from an artisanal fishery in Uruguay. J. Appl. Ichthyol. 25:78-82. Article

Seki, T., T. Taniuchi, H. Nakano, and M. Shimizu.

1998. Age, growth, and reproduction of the oceanic whitetip shark from the Pacific Ocean. Fish. Sci. 64:14-20.

Sidders, M. A., L. L. Tamini, J. E. Perez, and G. E. Chiaramonte. 2005. Biología reproductive del gatuzo Mustelus schmitti Springer, 1939 (Condrichtyes, Triakidae) en el area de Puerto Quequén, Provincia de Buenos Aires. Rev. Mus. Argent. Cienc. Nat., Nueva Ser. 7:89-101.

Skomal, G. B., and L. J. Natanson.

2003. Age and growth of the blue shark (Prionace glauca) in the North Atlantic Ocean. Fish. Bull. 101:627-639.

Smart, J. J., A. V. Harry, A. J. Tobin, and C. A. Simpfendorfer. 2013. Overcoming the constraints of low sample sizes to produce age and growth data for rare or threatened sharks. Aquat. Conserv. 23:124-134. Article

Smith, S. E., R. A. Mitchell, and D. Fuller.

2003. Age-validation of a leopard shark (Triakis semifasciata) recaptured after 20 years. Fish. Bull. 101:194-198.

Smith, W. D., G. M. Cailliet, and E. M. Melendez.

2007. Maturity and growth characteristics of a commercially exploited stingray, Dasyatis dipterura. Mar. Freshw. Res. 58:54-66. Article

Stevens, J. D., R. Bonfil, N. K. Dulvy, and P. A. Walker. 2000. The effects of fishing on sharks, rays, and chimaeras (chondrichthyans), and the implications for marine ecosystems. ICES J. Mar. Sci. 57:476-494. Article

Vooren, C. M.

1997. Demersal elasmobranchs. In Subtropical convergence environments: the coast and sea in the southwestern Atlantic (U. Seeliger, C. Odebrecht, and J. P. Castello, eds.), p. 141-146. Springer-Verlag, Berlin, Germany.

von Bertalanffy, L.

1938. A quantitative theory of organic growth (inquiries on growth laws. II). Human Biol. 10:181-213.

Yudin, K. G., and G. M. Cailliet.

1990. Age and growth of the gray smoothhound, Mustelus californicus, and the brown smoothhound, M. henlei, sharks from central California. Copeia 1990:191-204. Article

Zhu, L., L. Li, and Z. Liang.

2009. Comparison of six statistical approaches in the selection of appropriate fish growth models. Chin. J. Oceanol. Limnol. 27:457-467. Article 